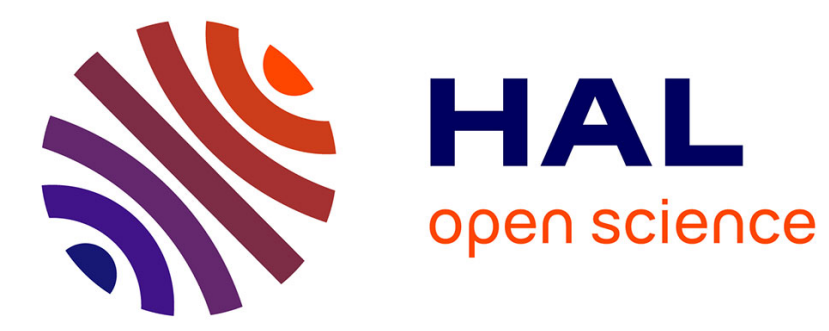

\title{
A study about $\mathrm{HCI}$ in practice of interactive system development using CMMI-DEV
}

Taisa Guidini Gonçalves, Káthia Marçal de Oliveira, Christophe Kolski

\section{To cite this version:}

Taisa Guidini Gonçalves, Káthia Marçal de Oliveira, Christophe Kolski. A study about HCI in practice of interactive system development using CMMI-DEV. 29ème conférence francophone sur l'Interaction Homme-Machine, AFIHM, Aug 2017, Poitiers, France. pp.169-177, 10.1145/3132129.3132146 . hal01577918

\section{HAL Id: hal-01577918 \\ https://hal.science/hal-01577918}

Submitted on 28 Aug 2017

HAL is a multi-disciplinary open access archive for the deposit and dissemination of scientific research documents, whether they are published or not. The documents may come from teaching and research institutions in France or abroad, or from public or private research centers.
L'archive ouverte pluridisciplinaire HAL, est destinée au dépôt et à la diffusion de documents scientifiques de niveau recherche, publiés ou non, émanant des établissements d'enseignement et de recherche français ou étrangers, des laboratoires publics ou privés. 


\section{A study about $\mathrm{HCl}$ in practice of interactive system development using CMMI-DEV}

T. G. Gonçalves LAMIH CNRS UMR 8201

Le Mont Houy cedex 9, France

taisa.guidinigoncalves@etu.univ-

valenciennes.fr

C. Kolski

LAMIH CNRS UMR 8201

Le Mont Houy cedex 9, France

christophe.kolski@univ-valenciennes.fr

\section{K. M. Oliveira}

LAMIH CNRS UMR 8201

Le Mont Houy cedex 9, France

kathia.oliveira@univ-valenciennes.fr

\section{ABSTRACT}

Human-Computer Interaction $(\mathrm{HCl})$ community has proposed many methods, techniques and standards for the development of interactive systems. Despite the great recognition of many of these approaches in academia, little is known about the state of practice in industry. To what extent are they known and used, while using a defined software process, to develop interactive systems? What is their level of use compared to software engineering approaches? This paper presents a study that we have conducted to answer these questions. This study is developed on top

Permission to make digital or hard copies of part or all of this work for personal or classroom use is granted without fee provided that copies are not made or distributed for profit or commercial advantage and that copies bear this notice and the full citation on the first page. Copyrights for third-party components of this work must be honored. For all other uses, contact the Owner/Author.

IHM '17, August 29-September 1, 2017, Poitiers, France

(C) 2017 Copyright is held by the owner/author(s).

ACM ISBN 978-1-4503-5109-6/17/08. https://doi.org/10.1145/3132129.3132146 
of one of the widest used software process improvement model: CMMI (Capability Maturity Model Integration). This paper presents the planning of this study, the research protocol and some initial results.

\section{CCS CONCEPTS}

- Human-centered computing $\rightarrow$; Empirical studies in $\mathrm{HCl}$

\section{KEYWORDS}

Human-computer Interaction, Interactive systems, Capability Maturity Model, Software engineering

\section{ACM Reference format:}

T. G. Gonçalves, K. M. Oliveira, and C. Kolski. 2017. A study about $\mathrm{HCl}$ in practice of interactive system development using CMMI-DEV. In Proceedings of 29eme Conference Francophone sur l'Interaction HommeMachine, Poitiers- Futuroscope, FR, Août 2017 (IHM 2017), 9 pages.

DOI: $10.1145 / 3132129.3132146$

\section{INTRODUCTION}

Undoubtedly, software process capability and maturity (SPCM) models are reached a large use in industry [14]. These models are collection of software engineering best practices that help organization to improve their process. SPCM models define practices for the development of any kind of system. They do not indicate any specific technique, method, or any specific approach; they describe what should be performed by the developers of software systems who are free to choose the approaches in order to implement the practices. One can suppose therefore that Human-Computer Interaction approaches should naturally be applied when SPCM models are used in the development of interactive systems. Based on this belief and taking profit of the large use of $\mathrm{CMMI}$ in industry, this paper presents a study that aims to investigate to what extent the $\mathrm{HCl}$ approaches are known and used by software developers. Moreover, to better analyze the results in a complete way considering the software development view we have also investigated if the developers know and use $\mathrm{HCl}$ approaches as they know and use Software Engineering approaches.

To that end, we first identified $\mathrm{HCl}$ approaches [6-7] adequate to support practices of the CMMI for development [2] based on $\mathrm{HCl}$ experts' opinion. After that, we looked in the literature software engineering approaches used to support the practices. Then we defined a specific research protocol and a questionnaire (survey), and we have surveyed enterprises of the top ten 
countries that use $\mathrm{CMMI}$ according to $\mathrm{CMMI}$ Institute ${ }^{1}$. In this paper, we present this research with some initial results from industry.

This paper is organized as follows. Section 2 briefly presents the main concepts of CMMI used in this study. Section 3 presents how we defined the $\mathrm{HCl}$ and $\mathrm{SE}$ approaches to support the practices of CMMI. Section 4 and 5 present the planning and execution of the study. Section 6 discusses the related works and section 7 presents some final remarks.

\section{A BRIEF OVERVIEW OF CMMI}

In the 1980s, the US Department of Defense (DoD) requested the development of a framework of criteria for evaluating its software providers. They financed the Software Engineering Institute (SEI) that presented in 1991 the Capability Maturity Model (CMM) [10]. In 2001, SEI proposed a new version of this model, the CMMI-DEV (Capability Maturity Model Integration for Developers), which encompasses the best practices of different models. The CMMI-DEV is a process model (best practices repository) for the realization of any type of product (or system). It is however in the development and maintenance of software that it is most used. It is currently in version 1.3 [2].

The best practices of CMMI-DEV are organized in-group to address specific goals of different process areas. The CMMI-DEV v1.3 presents 22 process areas that cover engineering, support, project and process management activities. The engineering process area is directed related to the development and evaluation of software systems (our interest in this paper) that are: Requirements Development, Technical Solution, Product Integration, Validation and Verification They encompass 40 specific practices (SP) grouped in 14 specific goals (SG). To illustrate, an example for the Requirements Development process area is the SG1-Develop Customer Requirements composed of two practices: SP1.1 Elicit Needs; SP1.2 Transform Stakeholder Needs into Customer Requirements.

Moreover, CMMI-DEV uses levels to describe an evolutionary path for an organization that wants to improve its processes. Two types of levels are defined for software process improvement (i) capability levels, improvement of one or more chosen process areas; and (ii) maturity levels, improvement of a set of pre-defined process area. Maturity levels are the most applied in industry organizing the process areas in a staged representation where each level is composed of several process areas. The staged representation has five maturity levels (1-5). Process areas of engineering are in the Defined level (3), which means the organization uses a defined process to develop its systems.

\section{SUPPORTING CMMI-DEV WITH HCI APPROACHES}

To apply the best practices of CMMI-DEV, software developers should use the existing workbench of techniques, methods, standards and methodologies. From this idea, our first

\footnotetext{
${ }^{1}$ http://partners.cmmiinstitute.com/find-partner-organization/
} 
Table 1: HCI categories x Examples

\begin{tabular}{ll}
\hline \multicolumn{1}{c}{ HCJ Category } & \multicolumn{1}{c}{ Examples } \\
\hline Task Analysis & CTT (Concur Task \\
Methods for & Tree); K-MAD (Kernel \\
HC] & of Model for Activity \\
& Description); HTA \\
& (Hjerarchical Task \\
& Analysis); SADT \\
& (Structured Analysis \\
& and Design \\
& Techrigue); GTA \\
& (Groupware Task \\
& Analysis). \\
\hline Evaluation & Heuristic evaluation; \\
methods for & Cognitjve \\
HCl review & wallethrough; \\
& Groupware \\
& walkthrough.
\end{tabular}

research activity was to scan all engineering specific practices from CMMI-DEV to identify where it was indicated that $\mathrm{HCl}$ issues should be taken into account.

To analyze the documentation, we initially seek explicit citations of $\mathrm{HCl}$ engineering by looking for: (i) $\mathrm{HCl}$ keywords (for example, external interface, end user, prototype); (ii) examples of techniques or methods of $\mathrm{HCl}$ (e.g. end-user task analysis, $\mathrm{HCl}$ models); and (iii) examples of work products (e.g. interface design specifications, user manual). Then, we looked for citations that were not directly related to $\mathrm{HCl}$ Engineering but that we could interpret in benefit of the use of it. We classify this information as implicit citations. Explicit and implicit citations were highlighted in the text and reviewed together in a final reading.

With all the identified citations and considering the literature of $\mathrm{HCl}$ (for example, $[3,11,12]$ ) and existing reviews of $\mathrm{HCl}$ approaches that support system development (for example, $[4,5,13]$ ), we proposed an initial set of approaches organized in $10 \mathrm{HCl}$ categories. For each $\mathrm{HCl}$ category, we included examples of methods, techniques, and standards. Table 1 presents some categories and their examples of approaches. Considering the identified citations in each practice, we associated each category as support for the accomplishment of the practices. For example, "Task Analysis Methods for $\mathrm{HCl}$ " was proposed as approaches to support the specific practices (SP1.1 and SP1.2) of the specific goal 1 of requirements development previous presented. In total, we had 33 propositions supported by $\mathrm{HCl}$ categories that were related to specific practices.

With this initial set, we interviewed twenty $\mathrm{HCl}$ experts (19 years of experience in average) well known in the $\mathrm{HCl}$ community. They were asked to analyze all propositions presented in a form (see example in Figure 1) and answer about their level of agreement justifying it. Each interview took in average 1.5 hours. The experts used the material to discuss and explain the use of several approaches in the development of interactive systems based on their own experience in academia and industry (14 experts declared have worked in the industry).

\begin{tabular}{|c|c|c|c|c|c|c|}
\hline \multirow{2}{*}{$\begin{array}{l}\text { Process Area } \\
\text { and Specific } \\
\text { Goal (SG) }\end{array}$} & \multirow{2}{*}{$\begin{array}{l}\text { Specific Practice } \\
\text { (SP) }\end{array}$} & \multirow{2}{*}{$\begin{array}{c}\text { Methods, } \\
\text { technjgues, } \\
\text { standards and } \\
\text { patterns of } \mathrm{HCl}\end{array}$} & \multicolumn{3}{|c|}{ Answer } & \multirow[t]{2}{*}{ Justification } \\
\hline & & & J agree & $\begin{array}{c}\text { partially } \\
\text { agree }\end{array}$ & $\begin{array}{l}\text { J don't } \\
\text { agree }\end{array}$ & \\
\hline $\begin{array}{l}\text { Requirements } \\
\text { Developrsent }\end{array}$ & $\begin{array}{ll}\text { SPI.J } & \text { Elicits } \\
\text { Needs } & \end{array}$ & $\begin{array}{l}\text { Task Analysis } \\
\text { Methods for HCI }\end{array}$ & & & $x$ & $\begin{array}{l}\text { "Task } \\
\text { Analysis is }\end{array}$ \\
\hline $\begin{array}{l}\text { SGI Develop } \\
\text { Customer } \\
\text { Requjirements }\end{array}$ & $\begin{array}{l}\text { Elicit stakeholder } \\
\text { needs, } \\
\text { expectations, } \\
\text { constraints, and } \\
\text { interfaces for all } \\
\text { phases of the } \\
\text { product lifecycle. }\end{array}$ & $\begin{array}{l}\text { Examples: CTT, } \\
\text { K-MAD, HJA, } \\
\text { SADT, GTA. }\end{array}$ & & & & $\begin{array}{l}\text { further } \\
\text { modeling } \\
\text { activity than } \\
\text { an elicitation } \\
\text { activity." }\end{array}$ \\
\hline
\end{tabular}

Figure 1: Simplified extract of the questionnaire (adapted from [7]) 
Table 2: HCI categories x SE categories

\begin{tabular}{|c|c|c|}
\hline$\#$ & HCI Categories & SE Categories \\
\hline I & $\begin{array}{l}\text { Technigues to } \\
\text { identify user } \\
\text { needs }\end{array}$ & $\begin{array}{l}\text { Technigues to } \\
\text { identify needs }\end{array}$ \\
\hline 2 & $\begin{array}{l}\text { Technjgues to } \\
\text { identjify user and } \\
\text { organjzational } \\
\text { requjernents }\end{array}$ & $\begin{array}{l}\text { Technigues to } \\
\text { identify } \\
\text { requjrements }\end{array}$ \\
\hline 3 & Task Modeling & $\begin{array}{l}\text { Software } \\
\text { Modeling }\end{array}$ \\
\hline 4 & $\begin{array}{l}\text { Standards and } \\
\text { Gujdelines for } \\
\text { HCl design }\end{array}$ & $\begin{array}{l}\text { Standards and } \\
\text { Guidelines for } \\
\text { design }\end{array}$ \\
\hline 5 & $\begin{array}{l}\text { Prototype for } \\
H C] \\
\text { requirements }\end{array}$ & $\begin{array}{l}\text { Prototype for } \\
\text { requirements }\end{array}$ \\
\hline 6 & $\begin{array}{l}\text { Techrigues to } \\
\text { valjidate HCl } \\
\text { requirements }\end{array}$ & $\begin{array}{l}\text { Technigues to } \\
\text { validate } \\
\text { requirernents }\end{array}$ \\
\hline 7 & $\begin{array}{l}\text { Architecture } \\
\text { patterns for HC] }\end{array}$ & $\begin{array}{l}\text { Architecture } \\
\text { Patterns for SE }\end{array}$ \\
\hline 8 & $\begin{array}{l}\text { Design patterns } \\
\text { for HCl }\end{array}$ & $\begin{array}{l}\text { Design } \\
\text { Patterns for SE }\end{array}$ \\
\hline 9 & $\begin{array}{l}\text { Techrigues for } \\
\text { jnteraction } \\
\text { modeling }\end{array}$ & $\begin{array}{l}\text { Interaction } \\
\text { modeling for } \\
\text { SE }\end{array}$ \\
\hline 10 & $\begin{array}{l}\text { Technigues for } \\
\text { HCI } \\
\text { documentation }\end{array}$ & $\begin{array}{l}\text { Techniques for } \\
\text { final } \\
\text { documentation }\end{array}$ \\
\hline ]1 & $\begin{array}{l}\text { Jterative and } \\
\text { Evolutionary } \\
\text { Prototypes } \\
\text { (systern } \\
\text { yersions) }\end{array}$ & $\begin{array}{l}\text { Prototype } \\
\text { (systern } \\
\text { versions) }\end{array}$ \\
\hline 12 & $\begin{array}{l}\text { Evaluation } \\
\text { methods for HCJ } \\
\text { yerification }\end{array}$ & $\begin{array}{l}\text { Verification } \\
\text { methods }\end{array}$ \\
\hline 13 & $\begin{array}{l}\text { Evaluation } \\
\text { methods for HCl } \\
\text { revjew }\end{array}$ & $\begin{array}{l}\text { Review } \\
\text { methods }\end{array}$ \\
\hline 14 & $\begin{array}{l}\text { Evaluation } \\
\text { methods for HCl } \\
\text { valjdatjon }\end{array}$ & $\begin{array}{l}\text { Valjdation } \\
\text { methods }\end{array}$ \\
\hline
\end{tabular}

Considering that we had 20 experts and 33 propositions, we had 660 responses to analyze. In general, we got $59 \%$ of agreement, $33 \%$ of partial agreement and $8 \%$ of disagreements. Analyzing all justifications from the partial agreement and disagreement, we modified the categories and the propositions, when it was applicable. As a final result, we evolved to $14 \mathrm{HCl}$ categories (see Table 2) and 39 propositions to support the practices of engineering processes areas. Some categories were renamed and others included. A detailed description of this study can be found in [6-7].

\section{PLANNING THE INVESTIGATION IN INDUSTRY}

To apply the best practices of CMMI-DEV, software developers should use the existing workbench of techniques, methods, standards and methodologies. From this idea, our first research activity was to scan all engineering specific practices from CMMI-DEV to identify where it was indicated that $\mathrm{HCl}$ issues should be taken into account.

Considering the large use of CMMI-DEV and the public information of accredited enterprises to CMMI Institute, we decided to ask to the contact person of these enterprises to what extent they know and use $\mathrm{HCl}$ approaches when working in the development of interactive systems. Moreover, we also planned to verify if they know and use these approaches as they know and use Software Engineering (SE) approaches when implementing the practices. To that end, we defined corresponding $\mathrm{SE}$ categories to each $\mathrm{HCl}$ category considering the well-known literature (see Table 2). We formalized the goal of this study according to [16] as follows: Analyze $\mathrm{HCl}$ and SE approaches for the purpose of characterization with respect to know and use of methods, techniques, standards and patterns from the point of view of software developers in the context of interactive system development.

The study was planned to be conducted off-line. A questionnaire was available in a web site being composed of two parts: (1) characterization of participants ${ }^{2}$ and (2) survey questions ${ }^{3}$ (see extract in Figure 2). In this way the participants (software developers) could answer the questionnaire in their own time and environment, not being monitored. For each category $(\mathrm{HCl}$ and SE), participants should answer to what extent they know and use the approaches when implementing the practices, using a Visual Analogue Scale (VAS) [15] - a horizontal line with two anchor points, from "None"(0) to "A lot" (10). The subjects were the contact persons of the associated enterprises to CMMI institute's database. Considering that our interest is the engineering process areas, we selected only enterprises that had CMMI-DEV equal or greater than 3 (defined level).

\footnotetext{
${ }_{3}^{2}$ https://surveytesis.000webhostapp.com/survey3/partone.php https://surveytesis.000webhostapp.com/survey3/parttwo.php
} 


\section{Table 3: Organizations x Responses}

\begin{tabular}{lcc}
\hline Country & $\begin{array}{c}* \\
\text { Enterprises }\end{array}$ & $\begin{array}{c}* \\
\text { Answer } \\
5\end{array}$ \\
\hline Brazil & 4 & 4 \\
\hline China & 18 & 0 \\
\hline France & 6 & 2 \\
\hline Jndia & 23 & 3 \\
\hline Japan & 5 & 2 \\
\hline Mexico & 7 & 1 \\
\hline $\begin{array}{l}\text { Republic } \\
\text { Of Korea }\end{array}$ & 7 & 0 \\
\hline Spajin & 7 & 3 \\
\hline $\begin{array}{l}\text { United } \\
\text { Kingdom }\end{array}$ & 10 & 0 \\
\hline $\begin{array}{l}\text { United } \\
\text { States }\end{array}$ & 119 & 6 \\
\hline \multicolumn{1}{c}{ Toisal } & 207 & 21 \\
\hline
\end{tabular}

To analyze and interpret the data we first computed the mean of the level of knowledge and use of each $\mathrm{HCl}$ category answered by the participants (that is the reason for choosing a continuous scale). Moreover, to analyze to what extent the participant know/use the practices related to SE approaches we formalized two hypotheses as follows:

- Null hypothesis

The software developers know and use $\mathrm{HCl}$ approaches as well as they know and use SE approaches when applying the same specific practices of CMMI-DEV engineering process area.

$\mathrm{H} 1_{0}$ : Know of $\mathrm{HCl}_{\mathrm{i}}-$ Know of $\mathrm{SE}_{\mathrm{j}}=0$

$\mathrm{H} 2_{0}$ : Use of $\mathrm{HCl}_{\mathrm{i}}-$ Use of $\mathrm{SE}_{\mathrm{j}}=0$ );

where $i$ is each of the $\mathrm{HCl}$ categories and its equivalent in $\mathrm{SE}$ is $j$.

- Alternative hypothesis

The software developers know and use $\mathrm{HCl}$ approaches less than $\mathrm{SE}$ approaches when applying the same specific practices of CMMI-DEV engineering process area.

$\mathrm{H} 1_{\mathrm{A}}$ : Know of $\mathrm{HCl}_{\mathrm{i}}-$ Know of $\mathrm{SE}_{\mathrm{j}}<0$ );

$\mathrm{H} 2_{\mathrm{A}}$ : Use of $\mathrm{HCl}_{\mathrm{i}}-$ Use of $\mathrm{SE}_{\mathrm{j}}<0$ ). Please, indicate your level of knowledge (I know) and level of use (I used) to each one of those methods, techniques, standards and patterns when in the implementation of Capability
Maturity models in enterprises you worked.

\begin{tabular}{|c|c|c|c|}
\hline \# & $\begin{array}{r}\begin{array}{c}\text { Process Area } \\
\text { (CMMI-DEV) }\end{array} \\
\end{array}$ & $\begin{array}{c}\text { Potential methods, techniques, standards and patterns from } \\
\text { Software Engineering (SE) }\end{array}$ & $\begin{array}{c}\text { Potential methods, techniques, standards and patterns from } \\
\text { Human-Computer Interaction ( } \mathrm{HCl})\end{array}$ \\
\hline & $\begin{array}{l}\text { Requirements Development } \\
\text { RD SP1.1 Elicit Needs }\end{array}$ & 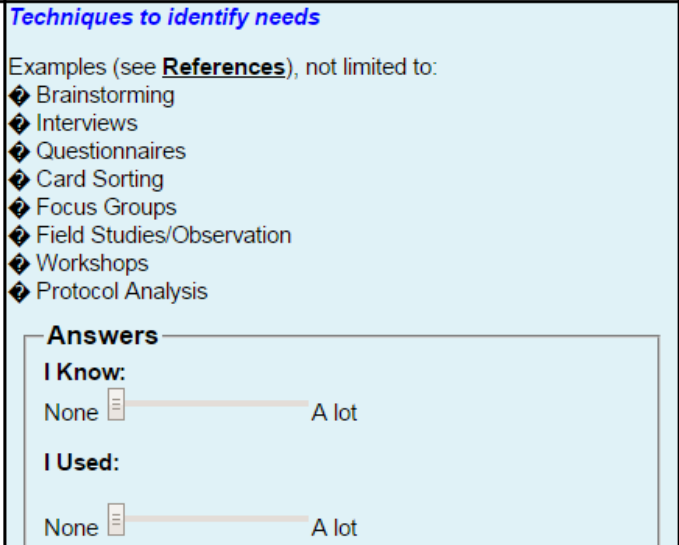 & 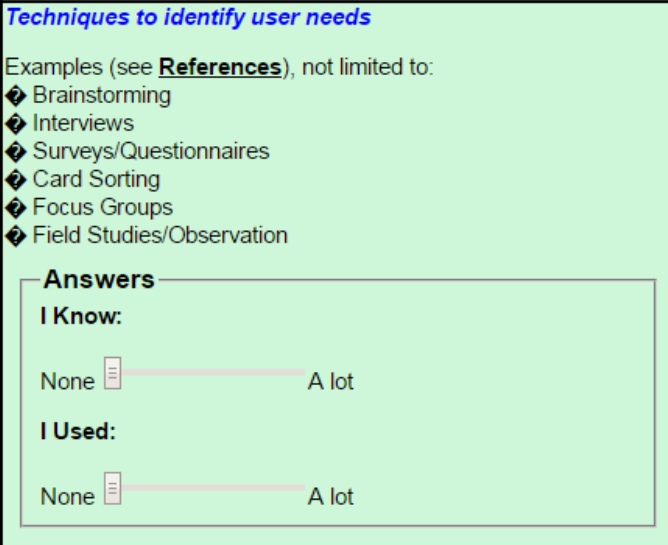 \\
\hline
\end{tabular}

Figure 2: Extract of the questionnaire available in the web site 
-Know of $\mathrm{HCl} \quad$ Know of $\mathrm{SE}$

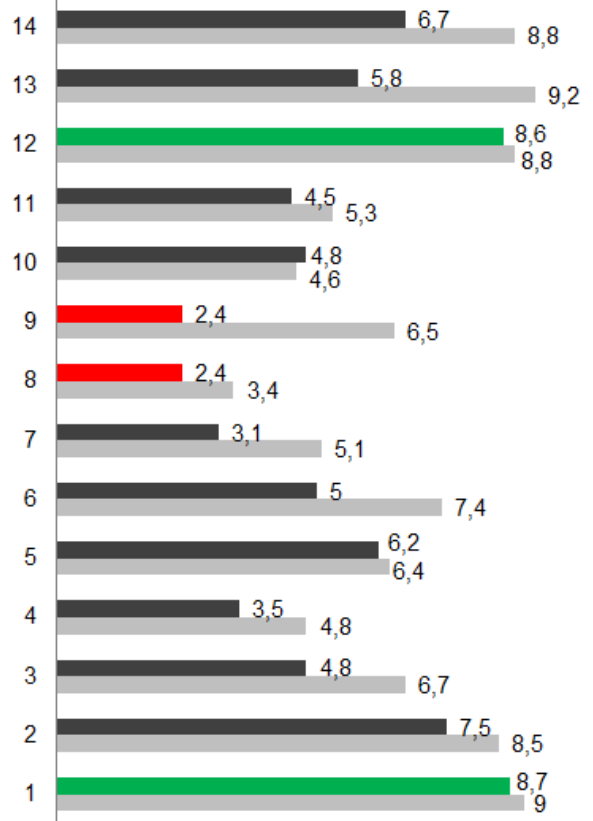

Figure 3: Results by category for Knowledge

\section{STUDY EXECUTION AND INITIAL RESULTS}

The CMMI Institute's database presents the data of 281 Partner Organizations that implement and evaluate CMMI-DEV from different countries. To reduce the scope, we decided to select the ten top countries in terms of official CMMI appraisals in the last years. Table 3 presents these countries that totalize 207 organizations, our population for this study. The survey request was sent by email with four recalls (6 months). Up to now, we got 21 answers (see Table 3). Considering the confidence level of $95 \%$, as usual recommended, we have $20 \%$ of margin of error considering this sample size.

By performing a descriptive analysis we note that about the profile of respondents, 15 participants worked as consultant in the enterprises; 4 were employees; and 2 have worked as consultant and were employees. They have between 9 and 28 years of experience in capability maturity models implementations. About the capability maturity level(s) supported in the implementations, $57 \%$ of the respondents have supported implementations in CMMI-DEV level 5, 4 and 3, and $29 \%$ declared that have supported only implementations in Level 3.

The participants answered their perception about to what extent they know and use the approaches by considering their experience in different enterprises developing several projects. We computed a total of 1228 enterprises and 5.025 projects. For the data (know and use), we computed the mean of answers (see Figure 3 for knowledge and Figure 4 for use) to each category (see Table 2). Analyzing only the $\mathrm{HCl}$ categories we note that the categories 1 and 12 presented the highest levels of knowledge and use. Looking in more detail by country (Figure 5 and Figure 6, we note that Japan is the country with the highest level of knowledge and use. We note also that France has the lowest level of knowledge for category 12 (Evaluation methods for $\mathrm{HCl}$ verification) and it is better only than Mexico in terms of use for the same category.

We believe that this result is justified since the approaches exemplified in all categories are quite similar for $\mathrm{SE}$ and $\mathrm{HCl}$. In the other hand, categories 8 and 9 presented the lowest level of knowledge and use, probably because the categories from design patterns and interaction modeling for $\mathrm{HCl}$ are very recently proposed.

Analyzing the results for SE categories, we note that: (i) the participants declared that they know more the approaches from the categories 1 (techniques to identify needs) and 13 (review methods); (ii) and they used more the approaches from the categories 6 (techniques to validate requirements) and 13 (review methods). As previously explained, the approaches exemplified in category 1 are quite similar for $\mathrm{SE}$ and $\mathrm{HCl}$. The approaches from category 13 are related to review methods that are very known and used in SE domain. Similarly, the category 6 presents approaches that are more used in SE domain to validated customer requirements than the approaches from category 14.

The results show that the level of knowledge and use for the category 10 (techniques for final documentation) is higher for $\mathrm{HCl}$ than for SE. This category is related to final documentation of the system, and we believe that $\mathrm{HCl}$ domain cares about this part because it is related to final 
-Use of $\mathrm{HCl} \quad$ Use of SE

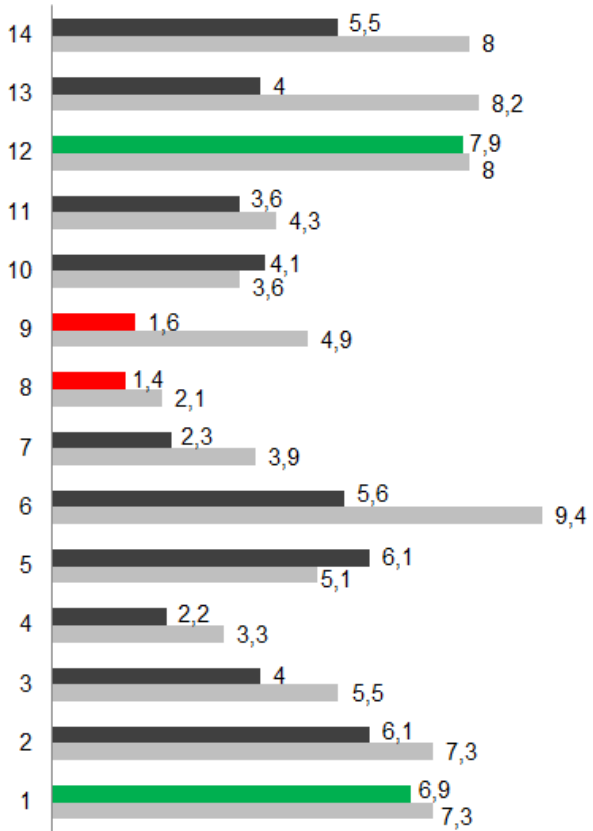

Figure 4: Results by category for Use

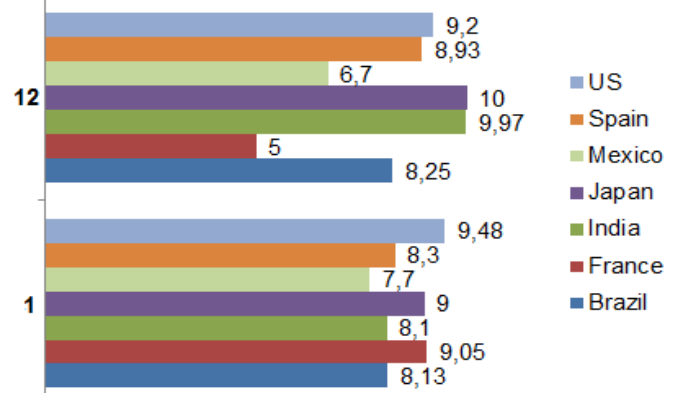

Figure 5: Results by country for Knowledge - Categories 1 and 12 documentation of the end user. In addition, for the category 5 the level of use is higher for $\mathrm{HCl}$ when compared with SE. This was expected since this category is normally used in $\mathrm{HCl}$ domain to validate user requirements and user interfaces.

\section{RELATED WORK}

For the best of our knowledge, no empirical study investigates the use of $\mathrm{HCl}$ approaches in the development of interactive systems following the CMMI-DEV. However we found three relevant studies that report the state of $\mathrm{HCl}$, usability and User Experience practice in the industry [1, 8, 9].

Ardito et al. [1] performed an experimental study conducted in Italy with software companies to investigate the use of Human-centered design. The authors did not used a measure to investigate the level of knowledge about $\mathrm{HCl}$, but they concluded that many software developers do not know well what usability is, and they know even less about UX.

Hussein et al. [8] performed an ethnographical study to understand how $\mathrm{HCl}$ is being incorporated in Malaysian enterprises. A high percentage of participants have never heard about $\mathrm{HCl}$ term (63.1\%) neither about Interaction Design (57.1\%). Even if $64.3 \%$ of the participants have heard of usability, $90.5 \%$ of they have never heard about usability standards of user interface.

Ogunyemi et al. [9] performed an exploratory investigation in Nigerian companies; they found that seventeen organizations (77\%) indicate to be aware of $\mathrm{HCl}$ and five organizations (23\%) are not aware of $\mathrm{HCl}$. Although 17 organizations claim to be aware of $\mathrm{HCl}$, the responses about the $\mathrm{HCl}$ methods applied in these companies do not support this claim.

Our results show that the knowledge and use of $\mathrm{HCl}$ approaches is low compared with the central point (5) of our scale. The mean of eight out of fourteen $\mathrm{HCl}$ categories is less than 5 for the knowledge. It is the same for the use of $\mathrm{HCl}$ categories. The findings of the related studies corroborate with our findings. In other words, the software developers do not know and use enough all $\mathrm{HCl}$ approaches to apply in practice.

\section{FINAL REMARKS}

This paper presents the planning and the initial results of a study that aims to identify to what extent software developers that follows CMMI-DEV, a well disseminated model of software engineering best practices, know and use $\mathrm{HCl}$ approaches. According to our descriptive results, we conclude for now that the knowledge and the use of $\mathrm{HCl}$ approaches in the industry is not yet enough to develop useful and usable interactive systems.

We continue to perform recalls to obtain more results of our survey and then perform complete statistics analysis. Our next steps will be to focus this investigation in only few countries for a deeper study. Moreover, we intend to define guidelines of how perform each CMMI-DEV engineering practice considering $\mathrm{HCl}$ approaches. 


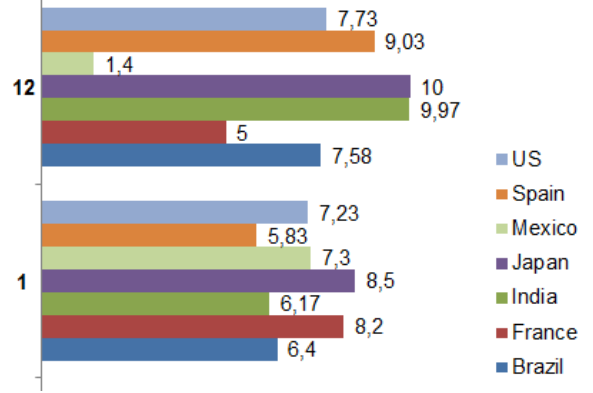

Figure 6: Results by country for Use Categories 1 and 12

\section{ACKNOWLEDGMENTS}

The authors thank the organizations that responded the survey and CAPES - Science without Borders Program for the financial support to this work. The authors thank also the anonymous reviewers for their useful remarks.

\section{REFERENCES}

[1] Carmelo Ardito, Paolo Buono, Danilo Caivano, and Maria F. Costabile. 2014. Investigating and promoting UX practice in industry: An experimental study. International Journal of Human-Computer Studies 72 (6), 542-551.

[2] CMMI Product Team. 2010. CMMI® for Development (CMMI-DEV), V1.3, (CMU/SEI-2010th-TR-033 ed.) Pittsburgh, PA, USA: Carnegie Mellon University.

[3] Catherine Courage and Kathy Baxter. 2005. Understanding your users: a practical guide to user requirements, methods, tools, and techniques. Morgan Kaufmann Publishers, San Francisco, CA

[4] Xavier Ferre, Natalia Juristo, and Ana M. Moreno. 2005. Which, when and how usability techniques and activities should be integrated. In Human-Centered Software Engineering - Integrating Usability in the Software Development Lifecycle, Seffah, A., Vanderdonckt, J., Desmarais, M.C. (Eds.). Springer, London, 173-200.

[5] Holger Fischer, Benjamin Strenge, and Karsten Nebe. 2013. Towards a holistic tool for the selection and validation of usability method sets supporting human-centered design. In Proceedings of DUXU/International Conference on Human-Computer Interaction, $252-26$.

[6] Taisa G. Gonçalves, Kathia M. Oliveira, and Christophe Kolski. 2016. HCI Engineering integrated with Capability Maturity Models: a study focused on Requirements Development. In Proceedings of the International Conference on Research Challenges in Information Science. IEEE, 633-644.

[7] Taisa G. Gonçalves, Kathia M. Oliveira, and Christophe Kolski. 2015. HCl engineering integrated with capability and maturity models. In Proceedings of 27th Conference on Interaction Homme-Machine (IHM 2015). ACM, New York, NY, 36:1-36:6.

[8] Idyawati Hussein, Murni Mahmud, and Alvin W. Yeo. 2010. HCl Practices in Malaysia: A Reflection of ICT Professionals' Perspective. In Proceedings of International Symposium in Information Technology (ITSim).15491554.

[9] Abiodun A. Ogunyemi, David Lamas, Emmanuel R. Adagunodo, Fernando Loizides, and Isaias B. Rosa. 2016. Theory, Practice and Policy: An Inquiry into the Uptake of $\mathrm{HCl}$ Practices in the Software Industry of a Developing Country. International Journal of Human-Computer Interaction 32(9), 665-681.

[10] Mark C. Paulk, Charles V. Weber, Bill Curtis, and Mary B. Chrissis. 1995. The Capability Maturity Model: Guidelines for Improving the Software Process. Addison-Wesley, Boston, MA.

[11] Andrew Sears and Julie A. Jacko. 2009. Human-Computer Interaction: Development Process. CRC Press.

[12] Ben Shneiderman and Catherine Plaisant. 2010. Designing the User Interface: Strategies for Effective HumanComputer Interaction. Addison-Wesley, MA.

[13] Williamson Silva, Natasha M. C. Valentim, and Tayana Conte. 2015. Integrating the Usability into the Software Development Process - A Systematic Mapping Study. In Proceedings of International Conference on Enterprise Information Systems. 105-113.

[14] Christiane G. von Wangenheim, Jean C. R. Hauck, Clenio F. Salviano, and Aldo von Wangenheim. 2010. Systematic Literature Review of Software Process Capability/Maturity Models. In Proceedings of SPICE.

[15] Mary E. Wewers and Nancy K. Lowe. 1990. A critical review of visual analogue scales in the measurement of clinical phenomena. Research in Nursing and Health 13, 227-236.

[16] Claes Wohlin, Per Runeson, Martin Höst, Magnus C. Ohlsson, Björn Regnell, and Anders Wesslén. 2012. Experimentation in Software Engineering. Springer-Verlag Berlin, Heidelberg. 
